\title{
Garjasmine unequivocally isolated from the Rubiaceae
}

\author{
Abdelhafeez M.A. Mohammed ${ }^{\mathrm{a}, \mathrm{b}}$, Philip H. Coombes ${ }^{\mathrm{a}}$, Neil R. Crouch ${ }^{\mathrm{a}, \mathrm{c}}$, Dulcie A. Mulholland ${ }^{\mathrm{a}, \mathrm{d}}$ \\ ${ }^{a}$ School of Chemistry, University of KwaZulu-Natal, Westville Campus, Private Bag X54001, Durban 4000, South Africa \\ ${ }^{b}$ Department of Chemistry, Alzaiem Alazhari University, PO Box 1432, Khartoum, Sudan \\ ${ }^{c}$ Ethnobotany Unit, South African National Biodiversity Institute, PO Box 52099, Berea Road 4007, South Africa \\ ${ }^{d}$ Division of Chemical Sciences, Faculty of Health and Medical Sciences, University of Surrey, Guildford, Surrey, GU2 \\ $7 X H$, United Kingdom
}

Keywords: Kraussia floribunda; Rubiaceae; Ixoroideae; Iridoid monoterpene; Garjasmine; Lignans; Flavonoids; Triterpenoids; Chemotaxonomy.

\section{Subject and source}

Kraussia floribunda Harv. (Rubiaceae; Ixoroideae) is a shrub or small tree occurring in Mozambique, Swaziland and South Africa. It is one of only four species in a genus restricted to southern and tropical Africa, and the adjacent island of Socotra (Bridson 1995). The leaves and stems of Kraussia floribunda were collected in Kloof, KwaZulu-Natal in March 2008 and a voucher specimen (N. Crouch 1168, NH) retained.

\section{Previous work}

Although the phytochemistry of related southern African genera in the Ixoroideae (e.g. Burchellia R.Br., Coffea L., and Gardenia J.Ellis) has been studied, to our best knowledge no evaluations of any member of Kraussia Harv. have been undertaken.

\section{Present study}

The air-dried, milled leaves (300 g) and stems (900 g) of $K$. floribunda were extracted separately and successively for $24 \mathrm{~h}$ each in a Soxhlet apparatus with $n$-hexane, DCM, EtOAc and $\mathrm{MeOH}$, yielding extracts of masses 14.0, 4.4, 8.8 and $70.0 \mathrm{~g}$, and 10.8, 5.2, 6.8 and $69.0 \mathrm{~g}$, respectively, after concentration in vacuo. Exhaustive gravity column chromatography over silica gel (Merck 9385 and 7229) and Sephadex LH-20, and PTLC on aluminium backed analytical TLC plates (Merck 5554), using $n$-hexane: $\mathrm{CH}_{2} \mathrm{Cl}_{2}: \mathrm{EtOAc:MeOH}$ mixtures yielded 10 compounds, whose structures were elucidated by extensive spectral (IR, MS, HRMS, 1D and 2D NMR) analysis and confirmed by comparison of spectral data with values found in the literature. The

Corresponding author: Tel +27 31260 1395; fax +27 312603091 .

Email address: coombesp@ukzn.ac.za (PH Coombes) 
isolated compounds were identified as the rare monoterpene iridoid garjasmine (2aS,4aS,7aS,7bS-tetrahydro2a-hydroxy-2H-1,7-dioxacyclopent $[c d]$ indene-5-carboxylic acid, methyl ester; CAS Registry Number 144868-43-9) 1 (3.5 mg) (Drewes et al. 1999), together with two lignans, (-)-4,4'-dihydroxy-3,3',5,5'tetramethoxy-7,9':7',9-diepoxylignan ((-)-syringaresinol) (15 mg) (Mbala 2005) and (-)-4,4'-dihydroxy-3,3'dimethoxy-7,9':7',9-diepoxylignan ((-)-pinoresinol) (Lin-gen et al. 1982); four flavones, 3',4',5,7-tetrahydroxyflavone (luteolin) (5 mg) (Wawer and Zielinska 2001), 3,3',4',5,7-pentahydroxyflavone (quercetin) (7 mg) (Mendez et al. 1995), 3,4',5,7-tetrahydroxyflavone (kaempferol) (10 mg) (Markham et al. 1978) and 3-O[2-O-( $\beta$ - $D$-xylopyranosyl)- $\beta$ - $D$-galactopyranosyl]kaempferol $(5 \mathrm{mg})$ (Larsen et al. 1982); an oleanolic acid derivative, 3-O-acetylolean-12-en-28-oic acid (5 mg) (Jo et al. 2005); and two phytosterols, sitosterol (15 mg) (Arigoni et al. 1997) and sitosterol-3-O- $\beta-D$-glucoside (10 mg) (Faizi et al. 2001).

\section{Chemotaxonomic significance}

All of the isolates except garjasmine $\mathbf{1}$ are common secondary metabolites. However, genipin-related compounds, including garjasmine $\mathbf{1}$, are of commercial pharmaceutical interest as their ability to inhibit uncoupling protein-2 (UCP2) activity suggests that they may potentially be useful in the treatment of diabetes mellitus and ischemia (Zhang et al. 2004). The trivial name afforded 1 implies its earlier isolation from Gardenia jasminoides J.Ellis, an East Asian species, also of the Rubiaceae (Ixoroideae). Nakatani et al. (1993), in synthesising 1 and referring to it as garjasmine, reported its earlier isolation "by Xu at Shanghai Institute of Materia Medica, Academia Sinica, Shanghai, China. The detail of the property of this compound [has] not appeared in the journal yet". To date, the anticipated report seems not to have formally appeared in print; by 1999 Drewes et al. were to note, with specific reference to garjasmine, that "numerous naturally occurring iridoids have a double bond in this $[\mathrm{C}-3 / \mathrm{C}-4]^{\S}$ position, and it is likely that such an iridoid, based on the gardiol skeleton, exists in nature." $\alpha$ - and $\beta$-Gardiols have been isolated from various rubiaceous taxa such as Burchellia bubalina Sims. (Drewes et al. 1999), Tocoyena formosa (Cham. \& Schltdl.) K.Shum. (Nakatani et al. 1993) and Rothmannia globosa (Hochst.) Keay (Bolzani et al. 1997). Recently, Chen et al. (2008) were the first to obtain naturally-occurring garjasmine, from the stems of Viburnum cylindricum Buch.-Ham. ex D.Don (Viburnaceae), a family with close affinities to both of the Adoxaceae and Caprifoliaceae (Heywood et al. 2007). These latter three families belong to the Dipsacales whereas the Rubiaceae is in the Gentianales. Chen et al. (2008) identified both epimers of gardiol in their Dipsacales subject (Viburnum), as well as garjasmine, implying that biosynthesis of $\mathbf{1}$ within this lineage may involve dehydration of either, or both, epimers, as demonstrated by Drewes et al. (1999) in their laboratory synthesis of $\mathbf{1}$ from the tosyl derivative of the $\beta$-epimer. However, biosynthetic studies on Gardenia jasminoides by Sampaio-Santos and Kaplan (2001) revealed an alternative pathway that could lead to garjasmine production without involving either epimer of

$\S$ given in the original text as C-2/C-3, presumably to match the numbering in the corresponding X-ray crystal structure (Fig. 5), which differs slightly from the systematic numbering of the iridoid skeleton. 
gardiol as a precursor. Accordingly, no chemotaxonomic relationship between the Gentianales and the Dipsacales is here implied by the coincident occurrence of this rare iridoid, but rather that different, yet convergent biosynthetic pathways are involved. The current finding in Kraussia floribunda of garjasmine $\mathbf{1}$ is notable as the first unequivocal report of this iridoid monoterpene in the Rubiaceae, and the second confirmed from a natural source.

\section{Acknowledgements}

We thank Mr. Bret Parel (ex UKZN), Dr. Philip Boshoff (Cape Technikon) and Dr. Collin Sparrow (Oxford University) for GC-EIMS, EIMS and HREIMS analyses, respectively, and Mr. Dilip Jagjivan (UKZN) for NMR spectra. The staff of the Mary Gunn Library (SANBI) are thanked for facilitating access to literature.

\section{References}

Arigoni, C., Sagner, S., Latzel, C., Eisenreich, W., Bacher, A., 1997. P. Natl. Acad. Sci. USA 94, 10600.

Bolzani, V.D.S., Izumisawa, C.M., Young, M.C.M., Trevisan, L.M.V., Kingston, D.G.I., Gunatilaka, A.L., 1997. Phytochemistry 46, 305.

Bridson, D.M., 1995. Kew Bulletin 50, 773.

Chen, X-Z., Wu, H-F., Lu, S-M., Li, B-G., Fang, D-M., Zhang, G-L., 2008. Helv. Chim. Acta 91, 1072.

Drewes, S.E., Horn, M.M., Munro, O.Q., Ramesar, N., Ochse, M., Bringmann, G., Peters, K., Peters, E-M., 1999. Phytochemistry 50, 387.

Faizi, S., Ali, M., Saleem, R., Irfanullah, G., Bibi, S., 2001. Magn. Reson. Chem. 39, 399.

Heywood, V.H., Brummitt, R.K., Culham, A., Seberg, O., 2007. Flowering plant families of the world. Firefly Books, Ontario, Canada. 331.

Jo, Y., Suh, J., Shin, M.H., Jung, J.H., Im, K.S., 2005. Arch. Pharm. Res. $28,885$.

Larsen, L.M., Nielsen, J.K., Sorensen, H., 1982. Phytochemistry 21, 1029.

Lin-gen, Z., Seligmann, O., Jurcic, K., Wagner, H., 1982. Planta Med. 45, 172.

Markham, K.R., Ternai, B., Stanley, R., Geiger, H., Mabry, T.J., 1978. Tetrahedron 34, 1389.

Mbala, M.B.P., 2005. M.Sc. Thesis, University of KwaZulu-Natal, Durban, South Africa.

Mendez, J., Bilia, A.R., Morelli, I., 1995. Pharm. Acta Helv. 70, 223.

Nakatani, K., Shimano, K., Hiraishi, A., Han, Q., Isoe, S., 1993. Chem. Lett. 1851.

Sampaio-Santos, M.I., Kaplan, M.A.C., 2001. J. Braz. Chem. Soc. 12, 144.

Wawer, I., Zielinska, A., 2001. Magn. Reson. Chem., 39, 374.

Zhang, C-V., Lowell, B.B., Porco, J.A., Shen, R., Lin, C.T., Krauss, S., 2004. PCT Int. Appl. WO 2004089926, 112 pp.

(CAN 141:366346; AN 2004:872789) 


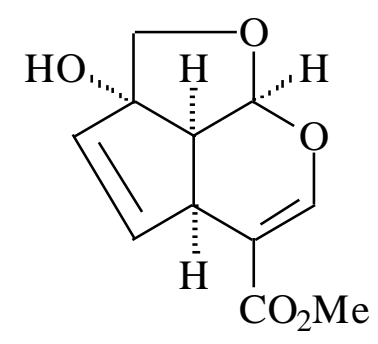

Figure 1. Chemical structure of garjasmine 1 